\title{
PENERAPAN METODE TANYA JAWAB DENGAN TEKNIK MENUNTUN DAN MENGGALI UNTUK MENINGKATKAN HASIL BELAJAR IPS SISWA KELAS VIII SMP NEGERI 1 PURBA TAHUN PEMBELAJARAN 2016/2017
}

\author{
Risma Hartati, Hertati Simanullang \\ Prodi Pendidikan Akuntansi, STKIP Riama Medan \\ rismahartati25@gmail.com
}

\begin{abstract}
This research was carried out in SMP N 1 Purba Year 2016/2017 semester Learning Ancient odd located at Jalan Merdeka No. 16 Tiga Runggu. The subject in this study is grade VIII totaling 36 persons while the object of the research was the application of faqs for improving student learning outcomes. This type of research this is a class action research consists of two cycles. Tools used in the collection of data is a test, and teachers did and provided at the time of learning to take place to find out the results of the learning improvement of IPS students. The results showed that pre cycle data on the results of the study, IPS has an average of $36 \%$. There are 23 students who completely (36\%) fewer criteria and 23 students who do not complete (64\%). On cycle I student learning results increased by an average of 53\%. There are 19 students who finished $(53 \%)$. Criteria that are not completely there are 17 students $(47 \%)$. In cycle II, experiencing an increase of an average of $92 \%$ with and detailed contained 33 students who are finished $(92 \%)$ and three students who do not complete $(8 \%)$. Individually grade VIII has declared the results of the study, IPS are high after learning by using learning faqs.
\end{abstract}

Keywords: Method of questioning, Learning Outcomes.

\begin{abstract}
Abstrak
Penelitian ini dilaksanakan di SMP N 1 Purba Tahun Pembelajaran 2016/2017 semester ganjil yang berlokasi di jalan Merdeka No. 16 Tiga Runggu. Subjek dalam penelitian ini adalah siswa kelas VIII yang berjumlah 36 orang sedangkan objek penelitian adalah penerapan tanya jawab untuk meningkatkan hasil belajar siswa. Jenis penelitian ini adalah penelitian tindakan kelas terdiri dari dua siklus. Alat yang digunakan dalam pengumpulan data adalah lembar tes dan diberikan pada saat pembelajaran berlangsung guna mengetahui peningkatan hasil belajar IPS siswa. Hasil penelitian menunjukkan pada data prasiklus bahwa hasil belajar IPS memiliki rata-rata 36\%. Terdapat 23 orang siswa yang tuntas (36\%) kriteria kurang dan 23 siswa yang tidak tuntas (64\%). Pada siklus I hasil belajar siswa meningkat dengan rata-rata 53\%. Terdapat 19 siswa yang tuntas (53\%). Kriteria yang tidak tuntas terdapat 17 siswa (47\%). Pada siklus II mengalami peningkatan sebesar rata-rata 92\% dengan perinci terdapat 33 siswa yang tuntas (92\%) dan 3 siswa yang tidak tuntas (8\%). Secara individual siswa kelas VIII dinyatakan memiliki hasil belajar IPS yang tinggi setelah dilakukan pembelajaran dengan menggunakan model pembelajaran tanya jawab.
\end{abstract}

Kata kunci: Metode tanya jawab, Hasil belajar.

PeTeKa (Jurnal Penelitian Tindakan Kelas dan Pengembangan Pembelajaran) $\mid 62$ 
PeTeKa (Jurnal Penelitian Tindakan Kelas dan Pengembangan Pembelajaran)

Vol 1 No 2 Tahun 2018 Hal 62-71

\section{PENDAHULUAN}

Pendidikan merupakan upaya untuk mengarahkan anak didik ke dalam proses belajar sehingga mereka dapat memperoleh tujuan belajar sesuai apa yang diharapkan. Dalam upaya peningkatan mutu pendidikan, banyak hal yang harus diperhatikan salah satunya adalah proses belajar mengajar yang merupakan salah satu unsur yang paling penting untuk mencapai tujuan pendidikan yang telah ditetapkan.

Menurut Fattah (2009) bahwa pendidikan adalah memanusiakan manusia muda. Pengangkatan manusia muda ke taraf mendidik. Sagala (2010) menegaskan bahwa satuan pendidikan adalah kelompok layanan pendidikan yang menyelenggarakan pendidikan pada jalur formal, nonformal, dan informal pada setiap jenjang dan jenis pendidikan. Satuan pendidikan dapat terwujud sebagai suatu sekolah, kursus, kelompoj belajar ataupun bentuk lain, baik menempati bangunan tertentu maupun yang tidak. Satuan pendidikan sebagai kelompok layanan pendidikan mempunyai Kegiatan utama melayani kebutuhan belajar peserta didik dalam berbagai ilmu dan keterampilan.

Peningkatan sumber daya manusia ditumbuhkembangkan melalui proses pendidikan yang hasilnya memungkinkan seseorang lebih manusiawi. Hal inilah merupakan tujuan dari proses pembelajaran tersebut, agar seseorang dapat berubah dari tidak mampu menjadi mampu atau tidak berdaya menjadi berdaya. Pendidikan juga merupakan usaha secara sengaja dari orang dewasa untuk dengan pengaruhnya meningkatkan si anak ke kedewasaan yang selalu diartikan mampu memikul tanggung jawab moril dari segala perbuatannya. Orang dewasa yang dimaksud adalah orang tua si anak atau orang yang di atas tugas atau kedudukannya mempunyai kewajiban untuk mendidik, misalnya guru sekolah, pendeta, kepalakepala asrama dan sebagainya.

Sekolah sebagai institusi pengelola pelayanan pendidikan diharapkan dapat memfungsikan tujuan dan efisien dalam menggunakan sumber daya tersebut. Guru merupakan komponen utama dalam penyelenggaraan pendidikan secara teknis di sekolah. Di tangan gurulah semua proses pemberdayaan sumber daya manusia berlangsung secara efisien dan efektif demi tercapainya tujuan pendidikan.

Slameto, (2010) Proses belajar mengajar merupakan suatu proses yang mengandung serangkaian perbuatan guru dan siswa atas hubungan timbal balik yang secara langsung dalam situasi edukatif untuk mencapai tujuan tertentu. Di mana tujuan pendidikan pada dasarnya adalah mengantar para siswa menuju pada perubahanperubahan tingkah laku intelektual, moral maupun sosial.

Di dalam mencapai tujuan tersebut, siswa berinteraksi dengan lingkungan belajar yang diatur guru melalui proses pembelajaran, metodologi pembelajaran, dan penilaian pembelajaran. Akan tetapi masalah yang dihadapi dunia pendidikan pada saat ini adalah masalah lemahnya proses pembelajaran. Dalam proses pembelajaran anak kurang didorong atau dimotivasi untuk mengembangkan kemampuan berpikir.

Sumiati, (2008) Dalam metode belajar selama ini yang menekankan kepada guru sebagai pusat informasi dan peserta didik sebagai informasi sehingga Kegiatan pembelajaran hanya mengutamakan aspek kognitif tanpa memperhatikan aspek afektif dan 
psikomotorik siswa. Pembelajaran yang dilakukan berorientasi kepada guru. Dalam Kegiatan pembelajaran ini guru cenderung menggunakan metode ceramah, hal ini menunjukkan bahwa metode tanya jawab belum dimanfaatkan dengan baik. Dilihat dari pengalaman guru menggunakan metode ceramah mengakibatkan siswa menjadi pasif, kurang berpartisipasi dalam pembelajaran yang menimbulkan kebosanan yang akhirnya akan berpengaruh pada hasil belajar siswa. Dalam metode ceramah ini komunikasian antara guru dengan siswa pada umumnya searah sehingga guru tidak dapat menguasai dan mengetahui batas kemampuan siswa terhadap materi pembelajaran.

Berdasarkan pengamatan penulis, bahwa kegiatan belajar mengajar guru pada mata pelajaran IPS cenderung menerapkan metode ceramah, kondisi belajar menunjukkan siswa hanya menerima materi dari pengajar, mencatat dan menghapal. Pembelajaran seperti ini membuat guru mendominasi Kegiatan pembelajaran sehingga menimbulkan ruang gerak terbatas bagi siswa sehingga mengakibatkan siswa pasif dan merasa bosan dalam mengikuti pembelajaran.

Salah satu metode mengajar yang melibatkan siswa secara aktif dalam metode tanya jawab dengan teknik menuntun dan menggali. Dalam pembelajaran metode tanya jawab ini berperan aktif adalah guru dan siswa dimana guru menuntun siswa untuk belajar dengan memberikan pertanyaanpertanyaan yang baik sebelum pelajaran dimulai, pada saat pelajaran berlangsung atau sesudah pelajaran. Setelah mendapat jawaban dari siswa kemudian guru menggali lagi jawabanjawaban tersebut dengan memberikan pertanyaan-pertanyaan yang lain untuk memotivasi siswa berpikir dan untuk mendapatkan jawaban-jawaban yang lebih sempurna.

Metode tanya jawab dapat meningkatkan kemampuan berpikir siswa dimana siswa tidak hanya menjadi pendengar saja akan tetapi siswa ikut berperan aktif di dalamnya.

Dengan demikian pemahaman metode tanya jawab perlu ditingkatkan agar dapat membantu siswa berperan aktif dalam Kegiatan belajar guna mengembangkan pola pikirnya karena siswa berpacu berpikir perlu untuk mengeluarkan pendapat dan menemukan gagasan atau ide-ide sehingga diperoleh jawaban atau masalah yang ada.

Karena rendahnya keaktifan dan hasil belajar siswa kelas VIII SMP khususnya mata pelajaran IPS, maka dilaksanakan penelitian tindakan kelas dengan judul: Penerapan Metode Tanya Jawab dengan Teknik Menuntun dan Menggali. Metode ini mampu meningkatkan kemungkinan berpikir kritis, partisipasi, demokrasi, mengembangkan sikap, motivasi, dan kemampuan berbicara. Dengan menerapkan metode tanya jawab diharapkan dapat meningkatkan keaktifan dan hasil belajar siswa SMP kelas VIII khususnya mata pelajaran IPS.

\section{METODE}

Lokasi penelitian ini dilaksanakan di SMP Negeri 1 Purba yang berlokasi di jalan Merdeka No. 16 Tiga Runggu, Kecamatan Purba, Kabupaten Simalungun Tahun Pembelajaran 2016/2017. Pelaksanaan penelitian ini dimulai bulan November semester ganjil.

Subjek penelitian ini adalah siswa kelas VIII SMP Negeri 1 Purba yang berjumlah 36 orang siswa. Objek dalam penelitian ini adalah penerapan 
PeTeKa (Jurnal Penelitian Tindakan Kelas dan Pengembangan Pembelajaran)

Vol 1 No 2 Tahun 2018 Hal 62-71

metode tanya jawab dengan teknik menuntun dan menggali untuk meningkatkan hasil belajar siswa.

\section{Jenis Penelitian}

Penelitian ini merupakan jenis Penelitian Tindakan Kelas yang menekankan kepada Kegiatan (tindakan) dengan mengujicobakan suatu metode pembelajaran yang diharapkan dapat memperbaiki dan meningkatkan proses belajar mengajar.

\section{Prosedur Penelitian}

\section{Siklus I}

1. Perencanaan

Adapun Kegiatan yang dilakukan dalam tahap ini adalah menetapkan lamanya pembelajaran pada setiap siklus, menyusun rencana pembelajaran, tes awal untuk mengetahui kemampuan awal siswa, membuat pedoman penilaian, membuat Lembar Kerja Siswa, menyiapkan lembar observasi yang digunakan untuk mengobservasi Kegiatan siswa selama Kegiatan belajar mengajar berlangsung.

2. Tindakan

Penyampaian materi pelajaran melibatkan guru dan siswa berperan aktif dalam proses pembelajaran dengan metode tanya jawab dengan menuntun dan menggali, melakukan evaluasi belajar berupa pilihan berganda, menganalisis evaluasi belajar dari perolehan nilai siswa untuk menilai tingkat keberhasilan siswa melalui penerapan metode tanya jawab dengan teknik menuntun dan menggali.

\section{Pengamatan}

Tahap pengamatan dilakukan oleh peneliti sendiri bersama guru mata pelajaran di dalam kelas saat Kegiatan pembelajaran sedang berlangsung. Pengamatan dilakukan untuk melihat motivasi siswa misalnya sikap, respon atau partisipasi siswa saat proses belajar mengajar berlangsung.

Tabel 1: Pelaksanaan Tindakan Siklus I

\begin{tabular}{|c|c|c|}
\hline No. & Tindakan & Hasil \\
\hline 1 & $\begin{array}{l}\text { Guru menyampaikan tujuan pembelajaran yang ingin } \\
\text { diicapai pada materi pelajaran }\end{array}$ & $\begin{array}{l}\text { Meningkatkan motivasi belajar } \\
\text { siswa }\end{array}$ \\
\hline 2 & $\begin{array}{l}\text { Guru menjelaskan materi pelajaran yang akan } \\
\text { dipelajari dan menjelaskan metode tanya jawab } \\
\text { dengan teknik menuntun dan menggali yang akan } \\
\text { diterapkan }\end{array}$ & $\begin{array}{l}\text { Siswa memahami materi dan } \\
\text { termotivasi untuk belajar }\end{array}$ \\
\hline 3 & $\begin{array}{l}\text { Guru menerapkan metode tanya jawab dengan teknik } \\
\text { menuntun dan menggali. Guru mengadakan latihan } \\
\text { post-test untuk mengetahui kemampuan siswa dan } \\
\text { sebagai evaluasi hasil siklus I }\end{array}$ & $\begin{array}{l}\text { Siswa berperan aktif dalam } \\
\text { belajar mengajar }\end{array}$ \\
\hline 4 & $\begin{array}{l}\text { Guru mengadakan latihan post-tes untuk mengetahui } \\
\text { kemampuan siswa dan sebagai evaluasi hasil siklusI }\end{array}$ & $\begin{array}{l}\text { Kemampuan siswa untuk } \\
\text { menerima materi dengan } \\
\text { metode tanya jawab dengan } \\
\text { teknik menuntun dan menggali }\end{array}$ \\
\hline 5 & Mengadakan refleksi tindakan & $\begin{array}{l}\text { Tingkat kemampuan siswa } \\
\text { memahami materi dengan } \\
\text { metode tanya jawab }\end{array}$ \\
\hline
\end{tabular}


Risma Hartati, dkk. Penerapan Metode Tanya Jawab Dengan Teknik...

4. Refleksi

Refleksi dilakukan berdasarkan hasil analisis dan pengamatan proses pembelajaran pada siklus I berlangsung untuk mengambil keputusan yang kemudian hasil refleksi ini digunakan sebagai dasar untuk tahap selanjutnya. Apabila pada tahap ini jumlah siswa $70 \%$ telah mencapai standar ketuntasan minimal maka langsung dilanjutkan ke siklus berikutnya. Maka penerapan metode tanya jawab dengan teknik menuntun dan menggali dalam penelitian ini dapat dikatakan berhasil. Apabila jumlah siswa belum mencapai $70 \%$ yang memenuhi standar ketuntasan minimal maka dilakukan dengan mengadakan remedial.

\section{Siklus II}

Siklus II merupakan tindakan lanjut dari siklus I dengan memperhatikan hasil belajar siswa untuk menentukan tindakan selanjutnya. Adapun langkah-langkah siklus II adalah:

\section{Perencanaan}

Dalam tahap ini guru mempersiapkan RPP, LKS sebagai alat evaluasi, instrument penelitian dan materi pelajaran yang akan diajarkan.

2. Tindakan

Dalam tahap ini belajar mengajar berlangsung seperti siklus I dimana guru dan siswa sama-sama berperan aktif sesuai dengan metode tanya jawab dengan teknik menggali dan menuntun. Pada siklus ini perlu memperhatikan kekurangan-kekurangan siswa pada siklus I, jadi pada siklus II ini pelaksanaan pembelajaran harus lebih memotivasi siswa untuk dapat berperan aktif dan menambah semangat siswa dalam belajar.

\section{Pengamatan}

Pengamatan ini dilakukan saat proses belajar mengajar berlangsung untuk merespon mata pelajaran. Dalam hal ini peneliti melihat kondisi belajar mengajar di kelas apakah sudah terlaksana sesuai dengan program yang diberikan dan apakah siswa mengalami peningkatan belajar dari siklus sebelumnya.

Tabel 2: Pelaksanaan Tindakan Siklus II

\begin{tabular}{|c|c|c|}
\hline No. & Tindakan & Hasil \\
\hline 1 & $\begin{array}{l}\text { Mengidentifikasi masalah baru dari hasil evaluasi } \\
\text { dan refleksi siklus I. }\end{array}$ & Masalah baru muncul \\
\hline 2 & $\begin{array}{l}\text { Guru menilai peningkatan hasil belajar dan } \\
\text { penguasaan materi setelah menerapkan metode } \\
\text { tanya jawab dengan teknik menuntun dan menggali }\end{array}$ & $\begin{array}{l}\text { Pencatatan melalui metode tanya } \\
\text { jawab dengan teknik menuntun } \\
\text { dan menggali dapat } \\
\text { meningkatkan hasil belajar siswa }\end{array}$ \\
\hline 3 & Mengevaluasi hasil siklus II & $\begin{array}{l}\text { Peningkatan kemampuan } \\
\text { menyelesaikan materi melalui } \\
\text { metode tanya jawab dengan } \\
\text { teknik menuntun dan menggali }\end{array}$ \\
\hline 4 & $\begin{array}{l}\text { Mengadakan refleksi pada siklus } \text { II secara } \\
\text { menyeluruh }\end{array}$ & $\begin{array}{l}\text { Peningkatan kemampuan siswa } \\
\text { melalui metode tanya jawab } \\
\text { dengan teknik menuntun dan } \\
\text { menggali, memotivasi belajar } \\
\text { siswa dan hasil belajar } \\
\text { meningkat }\end{array}$ \\
\hline
\end{tabular}


PeTeKa (Jurnal Penelitian Tindakan Kelas dan Pengembangan Pembelajaran)

Vol 1 No 2 Tahun 2018 Hal 62-71

4. Refleksi

Refleksi dilakukan berdasarkan hasil analisis data dan pengamatan selama proses pembelajaran pada siklus II dan mengadakan ulangan untuk mengetahui hasil belajar siswa sebagai dasar dalam pengambilan kesimpulan. Jika jumlah siswa $70 \%$ telah mencapai kriteria ketuntasan minimum, maka penerapan metode tanya jawab dengan teknik menuntun dan menggali dalam penelitian ini dikatakan berhasil. Jika hasil penilaian pembelajaran yang telah dilakukan hasilnya belum mencapai standar ketuntasan minimal maka dicari penyebab dan penyelesaiannya.

\section{Teknik Pengumpulan Data}

Sumber data dalam penelitian ini adalah siswa kelas VIII SMP Negeri 1 Purba. Data yang diperoleh dari hasil latihan pre-test dan post-test siklus I dan II.

\section{Teknik Analisis Data}

1. Reduksi Data

Data yang diperoleh dari hasil observasi dan hasil tes reduksi dan dikelompokkan dalam beberapa kategori kemudian diorganisasikan untuk memperoleh data informasi. Kegiatan ini bertujuan untuk melihat hasil tes siswa sehingga dapat diketahui peningkatan hasil belajar siswa.

2. Penyajian Data

Analisis data merupakan paparan kata sebagai kumpulan informasi yang terorganisasi dan terkategorikan sehingga memungkinkan adanya kumpulan data yang dianalisis dengan cara observasi hasil belajar siswa, dilihat dari data partisipasi dan keaktifan siswa terhadap Kegiatan pembelajaran melalui metode tanya jawab dengan teknik menuntun dan menggali dengan menggunakan lembar observasi.
Data hasil siswa dianalisis dengan menggunakan kriteria kelulusan minimum yang ditetapkan sekolah dan untuk mengetahui gambaran tentang hasil belajar siswa, maka seorang siswa dinyatakan telah mencapai kompetensi jika siswa memperoleh skor 70 dan kelas dinyatakan tuntas jika dari keseluruhan siswa mendapat skor ratarata kelas 70 atau $70 \%$.

a. Untuk mengetahui persentase kemampuan siswa secara individual dari setiap siklusnya menggunakan rumus

\section{HASIL DAN PEMBAHASAN}

\section{Deskripsi Hasil Penelitian}

Adapun hasil penelitian ini adalah sebagai berikut:

Siklus I

1. Pada siklus I sebelum pembelajaran tanya jawab dengan mengetahui kemampuan awal siswa dan hasil yang diperoleh adalah dari 36 siswa yang tuntas dalam belajar adalah 13 orang atau $36 \%$.

2. Setelah diberi tindakan yaitu dengan penerapan metode tanya jawab dengan teknik menuntun dan menggali pada siklus I maka diperoleh jumlah siswa yang tuntas dalam belajar adalah 19 orang atau $53 \%$ terjadi peningkatan sekitar 6 orang atau $16,6 \%$.

Pada Siklus II

1. Pada siklus II diperoleh jumlah siswa yang tuntas dalam belajar adalah 33 atau $92 \%$ terjadi peningkatan dari siklus I sekitar 14 orang atau $38,8 \%$.

Hasil yang diperoleh selama Kegiatan belajar mengajar dapat dilihat pada tabel berikut: 
Tabel 3: Hasil belajar siswa tes awal (Pre-Test) sebelum siklus I

\begin{tabular}{|c|c|c|c|c|}
\hline & \multicolumn{2}{|c|}{ Tuntas } & \multicolumn{2}{c|}{ Tidak Tuntas } \\
\hline $\begin{array}{c}\text { Jenis } \\
\text { Tes }\end{array}$ & $\begin{array}{c}\text { Jumlah } \\
\text { Siswa }\end{array}$ & $\%$ & $\begin{array}{c}\text { Jumlah } \\
\text { Siswa }\end{array}$ & $\%$ \\
\hline $\begin{array}{c}\text { Pre- } \\
\text { test }\end{array}$ & 13 & 36 & 23 & 64 \\
\hline
\end{tabular}

Pada pertemuan selanjutnya atau siklus I peneliti menerapkan pembelajaran metode tanya jawab dengan teknik menuntun dan menggali.

Tabel 4: Hasil belajar siswa Post Siklus I

\begin{tabular}{|c|c|c|c|c|}
\hline & \multicolumn{2}{|c|}{ Tuntas } & \multicolumn{2}{c|}{ Tidak Tuntas } \\
\hline $\begin{array}{c}\text { Jenis } \\
\text { Tes }\end{array}$ & $\begin{array}{c}\text { Jumlah } \\
\text { Siswa }\end{array}$ & $\%$ & $\begin{array}{c}\text { Jumlah } \\
\text { Siswa }\end{array}$ & $\%$ \\
\hline $\begin{array}{c}\text { Pre- } \\
\text { test }\end{array}$ & 13 & 36 & 23 & 64 \\
\hline
\end{tabular}

Adapun hasil belajar yang diperoleh siswa pada post-test siklus II adalah sebagai berikut:

Tabel 5: Hasil Belajar Siswa Post-Test Siklus II

\begin{tabular}{|c|c|c|c|c|}
\hline & \multicolumn{2}{|c|}{ Tuntas } & \multicolumn{2}{c|}{ Tidak Tuntas } \\
\hline $\begin{array}{c}\text { Jenis } \\
\text { Tes }\end{array}$ & $\begin{array}{c}\text { Jumlah } \\
\text { Siswa }\end{array}$ & $\%$ & $\begin{array}{c}\text { Jumlah } \\
\text { Siswa }\end{array}$ & $\%$ \\
\hline $\begin{array}{c}\text { Pre- } \\
\text { test }\end{array}$ & 33 & 92 & 3 & 8 \\
\hline
\end{tabular}

\section{Analisa Data}

Sebelum materi pelajaran diberikan kepada siswa dengan menerapkan metode tanya jawab dengan teknik menuntun dan menggali terlebih dahulu guru memberikan tes awal untuk mengetahui sejauh mana pengetahuan awal siswa terhadap materi yang diajarkan. Siswa yang tuntas ujian pada pre-test sebanyak 13 orang atau $36 \%$ dan siswa yang tidak tuntas sebanyak 23 orang atau $64 \%$. Setelah diterapkan pembelajaran metode tanya jawab dengan teknik menuntun dan menggali pada siklus I, diakhir pembelajaran dilaksanakan post-test dan siswa yang tuntas sebanyak 19 orang atau 53\%. Hasil belajar siswa mulai menunjukkan peningkatan yaitu meningkat dari 13 orang yang tuntas menjadi 19 orang.

Berdasarkan kriteria ketuntasan minimal yang ditetapkan di sekolah yaitu siswa dikatakan telah tuntas jika hasil belajar siswa telah mencapi skor 70. Pada siklus I siswa hanya 53\% yang masih mencapai skor 70. Maka dengan itu perlu dilanjutkan ke siklus II supaya maksimal siswa mencapai ketuntasan belajar.

Pada siklus II hasil belajar siswa menunjukkan peningkatan yang cukup tinggi karena pada siklus II jumlah siswa yang tuntas telah mencapai 33 orang atau $92 \%$ dan tidak tuntas 3 orang atau $8 \%$.

Dari penjelasan di atas dapat diketahui bahwa hasil belajar siswa dari siklus I ke siklus II dengan penerapan metode tanya jawab denagn teknik menuntun dan menggali mengalami peningkatan sebesar 38,8\%.

\section{Siklus I}

Pada tahap perencanaan peneliti mengadakan diskusi dengan guru mata pelajaran IPS tentang peneliti pelaksanaan tindakan kelas dan menjelaskan metode tanya jawab dengan teknik menuntun dan menggali yang dijadikan sebagai metode yang dapat meningkatkan hasil belajar siswa. Kemudian peneliti menyusun RPP sesuai dengan metode tanya jawab dengan teknik menuntun dan menggali. 
PeTeKa (Jurnal Penelitian Tindakan Kelas dan Pengembangan Pembelajaran)

Vol 1 No 2 Tahun 2018 Hal 62-71

Peneliti membuat pre-test untuk mengetahui kemampuan awal siswa terhadap materi yang akan diajarkan dan membuat post-test untuk mengetahui sejauh mana siswa memahami materi yang telah diajarkan. Pada tahap pelaksanaan sebagai berikut:

1. Peneliti memainkan perannya sebagai pengajar dengan menerapkan metode tanya jawab dengan teknik menuntun dan menggali yang sudah dirancang dalam rencana pelaksanaan pembelajaran (RPP) yang terdiri dari dua pertemuan.

2. Pada pertemuan peratama sebelum materi diajarkan, guru memberikan tes awal kepada siswa untuk mengetahui pengetahuan awal siswa tentang materi yang akan diajarkan.

3. Setelah pre-test dilaksanakan, peneliti menjelaskan penerapan metode tanya jawab dengan teknik menuntun dan menggali kemudian dengan metode tersebut peneliti mengajarkan materi pelajaran yang dirancang dalam rencana pelaksanaan pembelajaran.

4. Sebelum peneliti memberikan pelajaran, peneliti memberikan pertanyaan apa yang mereka ketahui tentang kebutuhan dan peneliti menyuruh beberapa siswa untuk memberikan penjelasan, kemudian peneliti menjelaskan materi.

5. Sebelum menutup, peneliti menyuruh berapa siswa menyimpulkan pelajaran yang sudah dipelajari.

6. Pada pertemuan kedua, peneliti mengulang kembali pelajaran sebelumnya dengan memberikan pertanyaan kepada siswa untuk mengingatkan kembali materi yang sudah dipelajari.

7. Pada pertemuan kedua peneliti menyuruh siswa membuka sub bab tentang materi kebutuhan sekaligus peneliti memberikan penjelasan dan dari penjelasan tersebut peneliti membuat pertanyaan untuk dijawab siswa.

8. Di akhir siklus, peneliti memberikan post-test kepada siswa tentang materi pokok yang sudah diajarkan selama dua pertemuan.

Pada tahap pengamatan dilakukan oleh peneliti sendiri. Peneliti mengamati aktivitas siswa selama pembelajaran berlangsung. Berdasarkan pengamatan pada pelaksanaan tindakan siklus I, ada peningkatan keaktifan siswa dalam belajar. Hal ini dapat dilihat dari seringnya siswa bertanya, menjawab pertanyaan yang diberikan peneliti.

Pada tahap refleksi, dilakukan pengkajian secara keseluruhan tindakan yang telah dilakukan berdasarkan data yang dikumpulkan. Hasil analisis data dari nilai pre-test sebelum siklus I dan nilai post-test pada siklus I. berdasarkan analisis data tersebut diketahui bahwa hasil belajar siswa dari pre-test ke posttest mengalami peningkatan. Pada saat pre-test dari 36 siswa, jumlah siswa yang tuntas belajar adalh 13 orang atau $36 \%$, sedangkan pada post-test siklus I jumlah siswa yang tuntas belajar menjadi 19 orang atau $53 \%$.

\section{Siklus II}

\section{Perencanaan}

Dari tahap refleksi dan evaluasi terhadap hasil pengamatan pada hasil I belum memperoleh $\geq 70$. Untuk memperbaiki kelemahan dan mempertahankan keberhasilan yang telah dicapai pada siklus I, maka pelaksanaan siklus II dilakukan perbaikan yaitu memotivasi siswa pada awal pembelajaran agar siswa lebih berani mengeluarkan pendapat maupun 
Risma Hartati, dkk. Penerapan Metode Tanya Jawab Dengan Teknik...

bertanya ketika guru bertanya atau meminta pendapat siswa.

Pada tahap ini peneliti kembali membuat RPP yang akan dilaksanakan pada siklus II. Pelaksanaan pada siklus II terdiri dari dua pertemuan yang dilakukan sama seperti siklus I. Pada siklus II ini telah mendominasikan Kegiatan belajar mengajar terhadap refleksi serta lebih memotivasi siswa agar lebih aktif bertanya dan memberikan pendapat dengan harapan peningkatan hasil belajar siswa agar sesuai dengan kriteria ketuntasan belajar minimal.

Pada siklus II ini peneliti lebih banyak menyuruh siswa bertanya dan mengeluarkan pendapat disbanding pada siklus I.

\section{Pelaksanaan}

Pembelajaran pada siklus II ini terdiri dari dua pertemuan sama seperti siklus I. Kegiatan pembelajaran dilaksanaan sesuai dengan RPP, dengan mempertimbangkan hal-hal yang ada pada tahap perencanaan, sama halnya dengan siklus I hanya saja pada siklus II ini lebih mendominasikan Kegiatan belahar mengajar terhadap refleksi dan evaluasi serta lebih memotivasi siswa agar lebih aktif dengan harapan ada peningkatan hasil belajar siswa sesuai dengan ketuntasan minimal. Pada pertemuan ini guru lebih banyak memberikan pertanyaan dan menyuruh siswa memberikan pendapat disbanding siklus I.

Pada pertemuan ini peneliti memberikan pertanyaan seputar materi dan memberikan kesempatan bertanya kepada siswa dan kemudian menyuruh beberapa siswa untuk memberikan pendapat untuk menanggapi pertanyaan temannya. Setelah pembelajaran berakhir maka guru memberikan posttest dengan jumlah soal 10 item.

Berdasarkan hasil post-test siklus II diperoleh jumlah siswa yang tuntas peningkatan dari siklus I. perolehannya daya serap siswa sebesar $85 \%$ dengan nilai $\geq 70$ telah tercapai.

\section{Pengamatan}

Seperti pada siklus sebelumnya, pada siklus ini pengamatan dilakukan secara langsung oleh peneliti pada saat Kegiatan pembelajaran berlangsung. Pada pertemuan ketiga, peneliti menyampaikan materi sesuai dengan metode tanya jawab dengan teknik menuntun dan menggali. Pada pertemuan ketiga ini didapati siswa lebih aktif memperhatikan, memberikan pertanyaan dan memberikan pendapat.

Pada pertemuan ke empat, peneliti memberikan kesempatan kepada beberapa orang siswa untuk membuat beberapa pertanyaan dan siswa yang lain berhak memberikan jawaban/pendapat atas pertanyaan dari temannya. Dalam Kegiatan ini siswa terlihat lebih aktif.

\section{Refleksi}

Setelah dilakukan pembelajaran pada siklus II dan diadakan refleksi dan evaluasi, diperoleh hasil belajar siswa dengan rata-rata 79,72. Hal ini menunjukkan peningkatan nilai rata-rata kelas dari siklus I ke siklus II adalah 14,45 . Ini juga sekaligus menandakan tidak perlu lagi dilanjutkan ke siklus berikutnya karena jumlah siswa yang tuntas belajar sebesar 92\%. Hasil tersebut menunjukkan bahwa siklus II sudah mencapai kriteria ketuntasan secara kalsikal yaitu $85 \%$ siswa harus memperoleh nilai $\geq 70$.

Peningkatan ini menunjukkan bahwa siswa sudah memahami standar kompetensi mengenai mengaktualisasikan sikap dan perilaku dengan menggunakan metode tanya jawab dengan menuntun dan menggali di kelas VIII SMP Negeri 1 Purba. 
PeTeKa (Jurnal Penelitian Tindakan Kelas dan Pengembangan Pembelajaran)

Vol 1 No 2 Tahun 2018 Hal 62-71

\section{SIMPULAN}

Dari hasil penelitian ini dapat disimpulkan bahwa metode tanya jawab pada mata pelajaran IPS dapat meningkatkan prestasi belajar siswa pada kelas VIII SMP Negeri 1 Purba. Hal ini ditunjukkan dengan hasil tindakan yang melalui dua siklus yang sebelumnya terdapat pra siklus yaitu sebelum menerapkan metode tanya jawab yang dijadikan perbandingan ketika siklus yaitu setelah menerapkan siklus metode tanya jawab. Presentasi ketuntasan belajar pada pra siklus $36 \%$ atau 13 orang meningkat $53 \%$ atau 19 orang dalam siklus I. Dan terjadi peningkatan pada siklus II sebesar $92 \%$ atau 33 orang. Dengan demikian metode tanya jawab dengan teknik dan menuntun dapat meningkatkan hasil belajar siswa pada pelajaran IPS.

Setelah memperhatikan kesimpulan di atas maka selanjutnya peneliti memberi saran sebagai berikut: Hendaknya guru memberi pemahaman awal kepada siswa tentang metode pembelajaran seperti tanya jawab. Hal ini sangat penting karena menentukan proses pembelajaran. Ketika proses pembelajaran berlangsung sangat penting guru memperhatikan siswa agar pembelajaran bisa maksimal seperti yang diinginkan. Jika ada diantara siswa yang gugup dalam bertanya atau menjawab maka tugas guru adalah membimbing siswa yang sedang mengalami kesulitan. Agar siswa tidak merasa takut atau bimbang. Hendaknya guru mempersiapkan pembelajaran materi IPS yang lebih kreatif agar siswa tidak merasakan jenuh atau bosan dalam proses pembelajaran. Bagi mahasiswa calon guru uang ingin menerapkan metode tanya jawab dengan teknik menuntun dan menggali pada penelitian selanjutnya dengan materi yang berbeda semoga skripsi ini dapat menjadi referensi agar peneliti selanjutnya menjadi lebih sempurna lagi.

\section{DAFTAR PUSTAKA}

Arikunto, Suharsimi, dkk. 2015. Penelitian Tindakan Kelas. Jakarta: Bumi Aksara.

Fattah, Nanang. 2009. Landasan Manajemen Pendidikan. Bandung: Rosda.

Kunandar. 2009. Langkah Mudah Penelitian Tindakan Kelas Sebagai Pengembangan Profesi Guru. Jakarta: Grafindo Persada.

Sagala, Saiful, H. 2010. Supervisi Pembelajaran dalam Profesi Pendidikan. Bandung: Alfabeta.

Slameto. 2010. Belajar dan FaktorFaktor yang Mempengaruhinya. Jakarta: Asdi Mahasatya.

Sumiati, Asra. 2008. Metode Pembelajaran. Bandung: Wacana Prima. 